\title{
PH DEPENDENT DIFFERENTIAL BINDING BEHAVIOR OF PRTOTEASE INHIBITOR MOLECULAR DRUGS FOR SARS-CoV-2
}

\author{
Hamdullah Khadim Sheikh ${ }^{\mathrm{a}^{*}}$, Tanzila Arshad ${ }^{\mathrm{b}}$, Zainab Sher Mohammad $^{\mathrm{c}}$ Iqra Arshad $^{\mathrm{d}}$, \\ ${ }^{\mathrm{e}}$ Mohtasheemul Hassan \\ ${ }^{*}$ Faculty of Pharmacy, University of Karachi, 75270 Karachi, Pakistan. \\ hamdullah.khadim.sheikh@gmail.com \\ ${ }^{b}$ Department of Applied Chemistry, University of Karachi, 75270 Karachi, Pakistan \\ tanzila_arshad2000@yahoo.com
}

${ }^{c}$ Physical therapy, Health Sciences, Riphah International University, Islamabad, Pakistan zainabmohammad696@gmail.com

${ }^{d}$ Research Centre for Modelling \& Simulation, National University of Science \& Technology iarshad.msbi18rcms@nust.edu.pk

${ }^{e}$ Faculty of Pharmacy, University of Karachi, 75270 Karachi, Pakistan. mohassan@uok.edu.pk

\section{Abstract}

In this research we used the structure of SARS-CoV-2 main protease (Mpro) for docking with Anti-HIV protease inhibitor drug molecules within $\mathrm{pH} 4-8$. By carrying out the variance analysis of binding energies at $\mathrm{pH} 4-8$, it was revealed that the binding energy and mode of interaction of the potential ligands with SARS-CoV-2 Mpro, was dependent on variation of $\mathrm{pH}$. We found out that two of the selected protease inhibitors have differential binding characteristics with changing $\mathrm{pH}$ hence their binding energies and mode of interaction depends upon intracellular $\mathrm{pH}$. This differential binding behavior can lead to development of $\mathrm{pH}$ selective potent drug molecules for binding with viral protease at lowered intracellular $\mathrm{pH}$ of virus infected cell.

Keywords: HIV; Drug; COVID-19; Docking; Protease inhibitors

\section{Introduction}

SARS-COV-2 is a single positive strand RNA virus [1] with enveloped structure. The known strategies to inhibit the SARS-COV2 virus have so far included development of drug molecules for interaction with host sites of coronavirus inside the human cell. One of such sites is RNA polymerase (RdRp), angiotensin-converting enzyme II (ACE2) entry receptor. Identified RdRp molecular inhibitors targeting ACE2 have showed less specificity and hence severe side effects [2][3]. Protease (Mpro) proteins also have proven to be potential drug targets for anti-viral drug molecules [4][5][6][7]. Recently, X-ray crystal structure of the SARS-COV-2 Mpro has been determined and thus provides an opportunity for structure-based protease inhibitor drug molecular designing [8]. Recently, several covalent binding Mpro inhibitors have been designed to target the protein formed by His41 and Cys145 [9] but covalent inhibitors have shown side effects too [10- 
Differential binding with protease of COVID-19

14]. In contrast, noncovalent protease inhibitors show fewer side effects. Recent researches are focusing on use of clinically approved drug molecules [15-17].

The virus-infected cells produce ATP during oxidative metabolism and also by glycolysis. Glycolysis converts glucose $\left(\mathrm{C}_{6} \mathrm{H}_{12} \mathrm{O}_{6}\right)$ into pyruvate $\left(\mathrm{CH}_{3} \mathrm{COCOO}^{-}+\mathrm{H}^{+}\right)$which further converts into lactate. Because of high rates of glycolysis and synthesis of lactate, $\mathrm{pH}$ of the cell turns acidic [18]. In this research, we used this differential character of the virus infected cells to check binding energies of anti-HIV protease inhibitors (1-10) at range of $\mathrm{pH}$ in between 4 to 8 . This can reveal if any of the selected molecules have $\mathrm{pH}$ selective binding with protease of an infected cell at reduced $\mathrm{pH}$. This research can lead to further derivatization of the known drug molecules for $\mathrm{pH}$ selective binding anti-viral drug for coronavirus.

\section{Experimental}

Docking simulations were performed using MOE2015.10 software. Structures of all drug molecules (1-10) were downloaded from PubChem website in .sdf format. By using Open Babel software [19] all structures were converted to. mol2 format. For preparation of receptor, the structure of PDB 6LU7 (resolution $2.16 \AA$ ) 33 of the SARS-COV-2 Mpro bound to a covalent N3 inhibitor was obtained from the Protein Data Bank [20] in .pdb format. Docking simulations were performed using MOE2015.10 software at $\mathrm{pH}$ 4-8.

\section{Results and Discussion}

Docking analysis was done on the basis of hydrogen bonding, Van der Waals and $\pi$ stacking interactions. Binding energies of
anti-HIV protease inhibitors (1-10) at $\mathrm{pH} 4-$ 8 are given in Table-1. All the selected molecules (1-10) are known HIV protease inhibitors which can be potent drugs for SARS-COV-2 infection based on their good interaction with binding sites on SARSCOV-2 specific protease (6LU7). These molecules also have shown good activity against COVID epidemics. Data demonstrates that all the selected protease inhibitors (1-10) bind with energy in between $7.5-10-\mathrm{kcal} / \mathrm{mol}$. The common site on protease that are responsible for the interactions with the drug molecules are hydrogen bonds forming Lewis basic sites. Variance in the binding energies of the selected molecules (1-10) in $\mathrm{pH}$ range of 4-8 revealed which drug molecules has the highest $\mathrm{pH}$ dependent interaction with the protease reception sites. By variance analysis, Tipranavir (8) showed the least variance while Indinavir (3) and Saquinavir (6) have shown the highest differentials of binding with the protease when the $\mathrm{pH}$ is varied between 4 and 8 , implying that glycolysis induced acidity in the cell may result in different behavior by Indinavir (3) and Saquinavir (6) thus forming the basis of a selective protease inhibitor for SARSCOV-2with least side effects. Binding energy change with $\mathrm{pH}$ for (1-10) is given inform of a plot in Figure-1. As can be seen in the plot, highest variation is shown by (3) and (6). Overall, Saquinavir (6) showed higher binding energy compared to Indinavir (3) Details of mode of interaction of Indinavir (3) and Saquinavir (6) and variation with changing $\mathrm{pH}$ are given in Table-2.1. and 2.2. respectively.

From Table-2.1., it has been found that in (3), OD1 ASN 142, CA THR 25, N THR 26, SD MET 49 and CA ASN 142 are 
Differential binding with protease of COVID-19

Lewis basic, hydrogen bond acceptor sites in the neutral range $\mathrm{pH}$ but these sites become protonated in the acidic $\mathrm{pH}$ below 7 and can no longer accept hydrogen bonds from the Bronsted acidic sites of the drug molecule (3). N GLY 143 is only active as a hydrogen bond acceptor in the neutral $\mathrm{pH}$ range. From Table-2.2., it has been found out that in (6) O GLU 166 and SD MET 165 act as hydrogen bond acceptor towards N10, $\mathrm{N} 11$ and $\mathrm{O} 5$ but at $\mathrm{pH}$ lower than 7 these sites get protonated and can no longer accept hydrogen bonds from Bronsted acidic sites of the drug molecule. SG CYS 145 acts as hydrogen bond acceptor towards $\mathrm{O} 2$ and N9 at $\mathrm{pH} 7$ but becomes hydrogen bond donor towards $\mathrm{O} 3$ at $\mathrm{pH} 6$ and towards $\mathrm{N} 6$ at the $\mathrm{pH} 4$.

\section{Conclusion}

We used protease as a receptor for binding anti-HIV protease inhibitors (1-10) within a range of $\mathrm{pH}$ between 4-8. It has been found that binding energies and modes of interaction are a function of $\mathrm{pH}$ for few Anti-HIV protease inhibitors when they are interacted with protease of SARS-COV-2 at increasingly acidic pH. Indinavir (3) and Saquinavir (6) were found to have the most variable binding energies with varying $\mathrm{pH}$. Hence, these molecules can lead to further development of $\mathrm{pH}$ selective protease inhibitors. Our group is working on further structural derivatization of these two molecules to make them more selective towards SARS-COV-2 virus infected cell protease with least possible side effects.

\section{Acknowledgement}

The authors thank the University of Karachi, Faculty of Pharmaceutical Sciences.

Table 1. Binding energy evaluation data by docking of molecules (1-10) with 6LU7 protease.

\begin{tabular}{|c|c|c|c|c|c|c|c|}
\hline S.no & Drug name & \multicolumn{5}{|c|}{ Binding energy -Kcal } & Variance \\
\hline & & $\mathbf{p H ~ 4}$ & $\mathbf{p H ~ 5}$ & $\mathbf{p H ~ 6}$ & $\mathbf{p H ~ 7}$ & $\mathbf{p H ~ 8}$ & \\
\hline $\mathbf{1}$ & Lopinavir & -8.6621 & -8.5899 & -8.6904 & -9.166 & -8.9895 & 0.060775 \\
\hline $\mathbf{2}$ & Ritonavir & -9.5703 & -9.5537 & -9.038 & -9.6335 & -9.1684 & 0.072897 \\
\hline $\mathbf{3}$ & Indinavir & -8.4765 & -8.1934 & -9.1431 & -9.9663 & -9.4476 & 0.517217 \\
\hline $\mathbf{4}$ & Atazanavir & -9.3476 & -9.1777 & -8.984 & -8.944 & -9.7643 & 0.110872 \\
\hline $\mathbf{5}$ & Nelfinavir & -8.3861 & -8.2052 & -8.3058 & -9.0882 & -8.2026 & 0.138129 \\
\hline $\mathbf{6}$ & Saquinavir & -9.0723 & -9.056 & -9.1467 & -10.39 & -9.7729 & 0.342589 \\
\hline $\mathbf{7}$ & Darunavir & -8.2729 & -8.8951 & -8.757 & -8.4063 & -8.3662 & 0.073151 \\
\hline $\mathbf{8}$ & Tipranavir & -7.8099 & -8.2747 & -8.0238 & -8.1536 & -8.1279 & 0.030422 \\
\hline $\mathbf{9}$ & Amprenavir & -8.7775 & -8.2611 & -8.5851 & -8.4314 & -8.1518 & 0.062523 \\
\hline $\mathbf{1 0}$ & Fosamprenavir & -9.041 & -8.7326 & -8.4335 & -8.3088 & -8.4717 & 0.085267 \\
\hline
\end{tabular}


Differential binding with protease of COVID-19

Table 2.1: Details of ligand and receptor interaction between (3) and 6LU7 protease.

\begin{tabular}{|c|c|c|l|c|c|c|}
\hline $\mathbf{p H}$ & $\begin{array}{c}\text { Total Binding Energy } \\
\text { Kcal/mol }\end{array}$ & Ligand & Receptor & Interaction & Distance & $\begin{array}{c}\text { Ligand Binding Energy } \\
\text { (kcal/mol) }\end{array}$ \\
\hline $\mathbf{8}$ & -9.4476 & N6 & N GLY 143 & H-acceptor & 3.29 & -2.3 \\
\hline & & N7 & O GLU 166 & H-donor & 3.40 & -1.0 \\
\hline & & N8 & OD1 ASN 142 & H-donor & 3.22 & -1.2 \\
\hline & & 6-ring & CA THR 25 & $\pi-\mathrm{H}$ & 4.61 & -1.1 \\
\hline & & 6-ring & N THR 26 & $\pi-\mathrm{H}$ & 4.13 & -2.0 \\
\hline $\mathbf{7}$ & -9.9663 & N9 & SD MET 49 & H-donor & 4.17 & -1.3 \\
\hline & & 6-ring & CA ASN 142 & $\pi$-H & 4.11 & -1.2 \\
\hline $\mathbf{6}$ & -9.1431 & O1 & O GLU 166 & H-donor & 2.79 & -2.6 \\
\hline & & N9 & O HIS 164 & H-donor & 2.88 & -2.6 \\
\hline & & C11 & SG CYS 145 & H-donor & 4.16 & -1.2 \\
\hline & & C11 & O HIS 164 & H-donor & 3.13 & -1.0 \\
\hline $\mathbf{5}$ & -8.1934 & N10 & OE1 GLU 166 & H-donor & 2.90 & -2.2 \\
\hline & & 6-ring & NE2 GLN 189 & $\pi$-H & 4.28 & -1.7 \\
\hline $\mathbf{4}$ & -9.5703 & N8 & O GLU 166 & H-donor & 3.14 & -3.3 \\
\hline
\end{tabular}

Table 2.2: Details of ligand and receptor interaction between (6) and 6LU7 protease.

\begin{tabular}{|c|c|c|l|l|c|c|}
\hline $\mathbf{p H}$ & $\begin{array}{c}\text { Total Binding Energy } \\
\text { Kcal/mol }\end{array}$ & Ligand & Receptor & Interaction & Distance & $\begin{array}{c}\text { Ligand Binding Energy } \\
\text { (kcal/mol) }\end{array}$ \\
\hline $\mathbf{8}$ & -9.7729 & N10 & O GLU 166 & H-donor & 3.58 & -0.6 \\
\hline & & N11 & SD MET 165 & H-donor & 3.36 & -2.3 \\
\hline $\mathbf{7}$ & -10.39 & O2 & SG CYS 145 & H-donor & 3.56 & -1.2 \\
\hline & & O5 & SD MET 165 & H-donor & 3.36 & -0.2 \\
\hline & & N9 & SG CYS 145 & H-donor & 3.89 & -1.5 \\
\hline & & N10 & OE1 GLN 189 & H-donor & 3.18 & -1 \\
\hline $\mathbf{6}$ & -9.1467 & O2 & OE1 GLN 189 & H-donor & 2.77 & -2.8 \\
\hline & & N9 & OE1 GLN 189 & H-donor & 3.12 & -3.3 \\
\hline & & C26 & SD MET 49 & H-donor & 4.15 & -0.8 \\
\hline & & O3 & SG CYS 145 & H-acceptor & 3.72 & -0.8 \\
\hline $\mathbf{5}$ & -9.056 & O 2 & N GLU 166 & H-acceptor & 2.95 & -2.4 \\
\hline $\mathbf{4}$ & -9.0723 & N6 & SG CYS 145 & H-donor & 4.10 & -2.3 \\
\hline & & C21 & O HIS 164 & H-donor & 3.34 & -0.7 \\
\hline & & C24 & SD MET 49 & H-donor & 4.25 & -1.7 \\
\hline & & O5 & N THR 26 & H-acceptor & 3.01 & \\
\hline
\end{tabular}


Differential binding with protease of COVID-19

Differential binding with protease of COVID-19

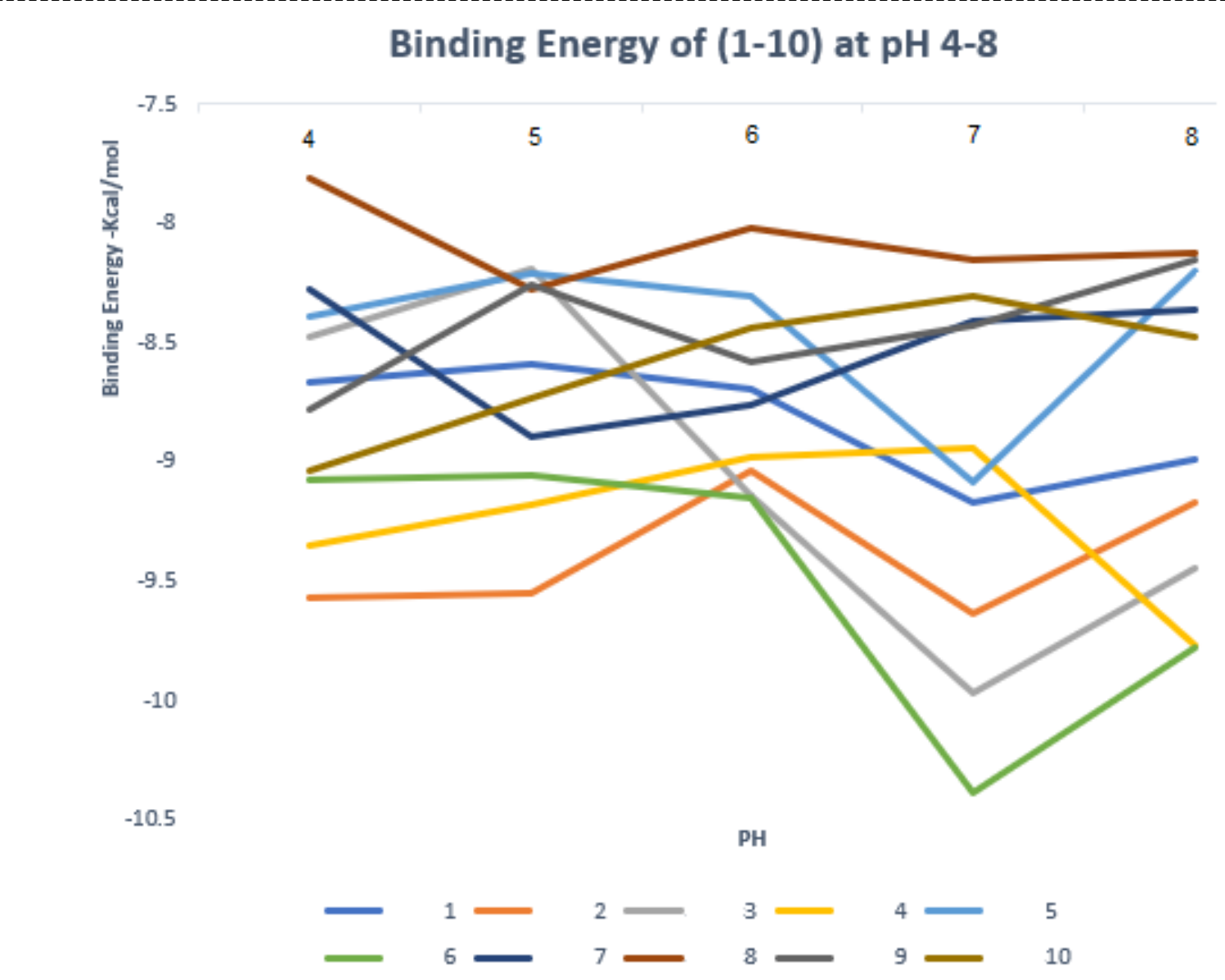

Figure 1. Plot of binding energies of (1-10) at pH 4-8. 
Differential binding with protease of COVID-19

Reference

1. Hui, D. S.; I Azhar, E.; Madani, T. A.; Ntoumi, F.; Kock, R.; Dar, O.; Ippolito, G.; Mchugh, T. D.; Memish, Z. A.; Drosten, C.; et al. The Continuing 2019-NCoV Epidemic Threat of Novel Coronaviruses to Global Health The Latest 2019 Novel Coronavirus Outbreak in Wuhan, China. International Journal of Infectious Diseases 2020, 91, 264-266. https://doi.org/10.1016/j.ijid.2020.01 .009 .

2. Han, D. P.; Penn-Nicholson, A.; Cho, M. W. Identification of Critical Determinants on ACE2 for SARSCoV Entry and Development of a Potent Entry Inhibitor. Virology 2006, $350 \quad$ (1), 15-25. https://doi.org/10.1016/j.virol.2006.0 1.029.

3. Li, G.; De Clercq, E. Therapeutic Options for the 2019 Novel Coronavirus (2019-NCoV). Nat Rev Drug Discov 2020, d41573-02000016-0.

https://doi.org/10.1038/d41573-02000016-0.

4. Cameron, C. E.; Castro, C. The Mechanism of Action of Ribavirin: Lethal Mutagenesis of RNA Virus Genomes Mediated by the Viral RNA-Dependent RNA Polymerase: Current Opinion in Infectious Diseases 2001, 14 (6), 757-764. https://doi.org/10.1097/00001432200112000-00015.
5. Chu, C. M. Role of Lopinavir/Ritonavir in the Treatment of SARS: Initial Virological and Clinical Findings. Thorax 2004, 59 (3), $252-256$. https://doi.org/10.1136/thorax.2003.0 12658.

6. Lu, I.-L.; Mahindroo, N.; Liang, P.H.; Peng, Y.-H.; Kuo, C.-J.; Tsai, K.C.; Hsieh, H.-P.; Chao, Y.-S.; Wu, S.-Y. Structure-Based Drug Design and Structural Biology Study of Novel Nonpeptide Inhibitors of Severe Acute Respiratory Syndrome Coronavirus Main Protease. J. Med. Chem. 2006, 49 (17), 5154-5161. https://doi.org/10.1021/jm060207o.

7. Blanchard, J. E.; Elowe, N. H.; Huitema, C.; Fortin, P. D.; Cechetto, J. D.; Eltis, L. D.; Brown, E. D. High-Throughput Screening Identifies Inhibitors of the SARS Coronavirus Main Proteinase. Chemistry \& Biology 2004, 11 (10), 1445-1453.

https://doi.org/10.1016/j.chembiol.20 04.08.011.

8. Liu, X.; Zhang, B.; Jin, Z.; Yang, H.; Rao, Z. The Crytal Structure of 2019-NCoV Main Protease in Complex with an Inhibitor N3. $P D B$ 2020.

https://doi.org/10.2210/pdb6lu7/pdb.

9. Paasche, A.; Zipper, A.; Schäfer, S.; Ziebuhr, J.; Schirmeister, T.; Engels, B. Evidence for Substrate BindingInduced Zwitterion Formation in the Catalytic Cys-His Dyad of the SARS-CoV Main Protease. 
Differential binding with protease of COVID-19

Biochemistry 2014, 53 (37), 59305946.

https://doi.org/10.1021/bi400604t.

10. Lee, H.; Mittal, A.; Patel, K.; Gatuz, J. L.; Truong, L.; Torres, J.; Mulhearn, D. C.; Johnson, M. E. Identification of Novel Drug Scaffolds for Inhibition of SARSCoV 3-Chymotrypsin-like Protease Using Virtual and High-Throughput Screenings. Bioorg. Med. Chem. 2014, 22 (1), 167-177. https://doi.org/10.1016/j.bmc.2013.1 1.041 .

11. Ghosh, A. K.; Xi, K.; Johnson, M. E.; Baker, S. C.; Mesecar, A. D. Progress in Anti-SARS Coronavirus Chemistry, Biology and Chemotherapy. In Annual Reports in Medicinal Chemistry; Elsevier, 2006; Vol. 41, pp 183-196. https://doi.org/10.1016/S00657743(06)41011-3.

12. Tuley, A.; Fast, W. The Taxonomy of Covalent Inhibitors. Biochemistry 2018, 57 (24), 3326-3337. https://doi.org/10.1021/acs.biochem. $8 \mathrm{~b} 00315$.

13. Turk, B. Targeting Proteases: Successes, Failures and Future Prospects. Nat Rev Drug Discov 2006, 5 (9), 785-799. https://doi.org/10.1038/nrd2092.

14. Ghosh, A. K.; Gong, G.; GrumTokars, V.; Mulhearn, D. C.; Baker, S. C.; Coughlin, M.; Prabhakar, B. S.; Sleeman, K.; Johnson, M. E.; Mesecar, A. D. Design, Synthesis and Antiviral Efficacy of a Series of Potent Chloropyridyl Ester-Derived SARS-CoV 3CLpro Inhibitors. Bioorg. Med. Chem. Lett. 2008, 18 (20), 5684-5688. https://doi.org/10.1016/j.bmcl.2008.0 8.082 .

15. Li, Y.; Zhang, J.; Wang, N.; Li, H.; Shi, Y.; Guo, G.; Liu, K.; Zeng, H.; Zou, Q. Therapeutic Drugs Targeting 2019-NCoV Main Protease by HighThroughput Screening. bioRxiv 2020, 2020.01.28.922922. https://doi.org/10.1101/2020.01.28.9 22922.

16. Xu, Z.; Peng, C.; Shi, Y.; Zhu, Z.; $\mathrm{Mu}, \quad$ K.; Wang, X.; Zhu, W. Nelfinavir Was Predicted to Be a Potential Inhibitor of 2019-NCov Main Protease by an Integrative Approach Combining Homology Modelling, Molecular Docking and Binding Free Energy Calculation. bioRxiv 2020, 2020.01.27.921627. https://doi.org/10.1101/2020.01.27.9 21627.

17. Liu, X.; Wang, X.-J. Potential Inhibitors for 2019-NCoV Coronavirus $\mathrm{M}$ Protease from Clinically Approved Medicines. bioRxiv 2020, 2020.01.29.924100. https://doi.org/10.1101/2020.01.29.9 24100.

18. Liu, H.; Maruyama, H.; Masuda, T.; Honda, A.; Arai F. The Influence of Virus Infection on the Extracellular $\mathrm{pH}$ of the Host Cell Detected on Cell Membrane. Front Microbiol. 2016, 
Differential binding with protease of COVID-19

17(7), $\quad 1127 . \quad$ https://doi:

10.3389/fmicb.2016.01127.

19. O'Boyle, N.M. Open Babel: An open chemical toolbox. J Cheminform.
2011, 3, 33. 7;3:33. https://doi: 10.1186/1758-2946-3-33.

20. Berman. H.; The Protein Data Bank: a historical perspective. Acta Cryst. A. 2008, 47, 88-95. 